\title{
COMO EU TRATO AS DERMATITES PERIESTOMA*
}

\author{
Vera Lúcia Conce ifáo de Gouveia Santos**
}

SANTOS, V. L. C. de G. Como eu trato as dermatites periestoma. Rev. Enc. Enf. USP, v. 28. ,n1. ,p. 67-71, abril, 1994.

Uma das complicaçōes mais freqüentes, durante o processo de reabilitaçòo do ostomizado, é a dermatite periestoma que pode e deve ser evitada através de uma assistência especializada. A autora faz uma revisão apontando os principais fatores causais e associados que acarretam as dermatites, sua classificaçāo e os princfpios de tratamento e prevenção.

UNITERMOS: Ostomia. Dermatite

\section{INTRODUÇẢO}

O processo de reabilitação do ostomizado é bastante complexo exigindo, por isso mesmo, a intervençáo de diversos profissionais que, através de um trabalho integrado, possam atingir efetivamente os objetivos inicialmente propostos.

Em estomaterapia, a Enfermagem tem como uma das responsabilidades mais significativas, a manutenção da integridade da pele periestoma, como parte de um tríduo que necessita manter-se em equilibrio: estoma - pele periestoma e dispositivo.

Diversos estudos têm mostrado que dentre as complicaçōes relacionadas aos estomas intestina is, seja colostomia ou ileostomia, as mais freqüentes sāo as dermatites periestoma. Embora o avanço tecnológico tenha aperfeiçoado as técnicas cirúrgicas e de cuidado dos estomas, além dos dispositivos específicos que vêm contribuindo para a redução da ocorrência das dermatites periestoma, os índices ainda têm se apresentado elevados (até 70\%)

Evidentemente existem variáveis que influenciam a manutenção da integridade da pele e que devem ser consideradas na avaliação do ostomiza$\mathrm{do}^{3,8,10}$ :

- características da pele (também relacionadas à idade);

\footnotetext{
- Tema apresentado durante $041^{\circ}$ Congresso Brasileiro de Coloproctologia, Poços de Caldas, 1992.

- Enfermeira. Assistente do Departamento de Enfermagem Médico-Cirúrgica da Escola de Enfermagem da USP. EstomaterapeuLa.
} 
- características qualitativas e quantitativas do efluente;

- doença de base e tratamento (como radioterapia, quimioterapia, corticoesteroideterapia e outras);

- características do estoma quanto à origem a natômica, localizaçāo na parede abdominal e existência de complicaçōes (retraçāo, estenose, prolapso);

- doenças de pele associadas (psoriase, eczema, pênfigo, etc.);

- hérnia paraestomal (geralmente paracolostômica);

- perfil do autocuidado ou do cuidado prestado por outrem e

- características do equipamento coletor utilizado (tipo, com ou sem barreira protetora, tipo de barreira, adesivo, uso de acessórios, disponibilidade e outras).

\section{CLASSIFICAÇĀO}

Várias propostas de classificação das dermatites periestoma têm sido feitas, porém, genericamente, têm-se adotado as formas leve, moderada e grave (severa ou intensa), que incluem as diversas alteraçōes dermatológicas relacionadas a cor, relevo, coleçōes líquidas, espessura e perda tecidual $\left.\right|^{1,6,10}$.

Segundo BORGLUND ${ }^{2}$, HAMPTON ${ }^{4}$, ROTHSTEIN ${ }^{8}$ e WATT ${ }^{10}$, quanto às causas, as dermatites periestoma podem ser:

- irritativa ou de contato, que constitui o tipo mais comum, mesmo em nosso meio e que se estabelece quando as células sofrem agressão tóxica direta ou tornam-se inflamadas (sem desenvolver sensibilizaçāo). O processo irritativo possui 2 fases, podendo ser iniciado por determinados agentes como fezes, enzimas, produtos desodorantes ou solventes, sabōes, mudanças radicais no $\mathrm{pH}$ e, uma vez instalada a inflamaçāo, o processo pode ser maximizado e continuado por outros agentes, como saböes e traumas fisicos;

- alérgica, também bastante freqüente, cujo agente pode ser qualquer elemento do dispositivo usado (adesivo, barreira ou plástico). Vale lembrar que, uma vez desenvolvida a sensibilização, esta é permanente;

- por trauma mecânico, que engloba desde as técnicas abrasivas de limpeza e remoçāo traumática dos adesivos e barreiras, resultando em "esfoladura" da epiderme, até a contínua friç̧ão ou pressão oriun- 
da de dispositivos mal adaptados ou de cintos muito apertados, que sảo os tipos mais encontrados em nosso meio;

- foliculite, originada por remoçảo traumática dos pelos da área periestoma ou por inadequada técnica de remoção do dispositivo. A infeç̧ão do folículo piloso é geralmente promovida por estafilococo coagulase positiva;

- lesão pseudoverrucosa (hiperplasia), que se desenvolve na borda mucocutânea, pela exposição crônica da pele ao efluente (mais freqüentemente - urina), provocada por inadequaçāo do diâmetro de abertura do dispositivo ou por alteraçōes da forma e profusāo do estoma, que, podem levar a vazamentos freqüentes ou ao derretimento precoce das barreiras protetoras;

- infecçōes por fungos, especialmente por Candida Albicans. Vazamento do efluente através da bolsa, a perspiração e pele irritada, são situaçōes que propiciam a sua instalaçào. Além destas, outras condiçōes favoráveis ao seu desenvolvimento são o Diabetes mellitus, imunossupressão, mielossupressāo e outras, que geram alteraçōes imunológicas e/ou da flora corporal;

- por radiação e quimioterapia, causadas pela destruiçáo celular e "esfoladura" mecânica da epiderme quando barreiras e adesivos são retirados. Além disso, o uso de resinas que contêm metais pesados (como zinco e bismuto), podem causar irradiaçảo secundária resultando em uma dose mais elevada ao nível da pele;

Além destas, que constituem situaçōes mais comuns, existem ainda outros tipos de lesóes da pele periestoma que demandam a atuação da estomaterapeuta $e$, muitas vezes, o encaminhamento do paciente para o dermatologista e mesmo para o cirurgião colo-proctologista, para um outro nível de intervenção, eventualmente mais radical. Assim temos: 08 transplantes de mucosa intestinal em superficie abdominal; o pioderma grangrenoso; a dermatomiosite; infecçāo por Herpes simplex e Herpes zoster; infeç̧ōes bacterianas; pooríasis; pênfigo e tumores malignos (primários ou secundários) $2,4,8,10$.

\section{PREVENÇÃO E TRATAMENTO}

Como em todas as áreas da Saúde, também em Estomaterapia, a equipe multiprofissional deveria ter como uma das metas principais, a prevenção das complicaçōes, o que, no caso das dermatites periestoma, poderia ser atingido através de dois aspectos bastante simples: 
- o emprego de uma boa técnica cirúrgica em pacientes bem preparados, e

- a proteção da pele propriamente dita, através do uso de dispositivos e agentes reconhecidamente nāo-tóxicos e de um adequado processo de ensino e aprendizagem do autocuidado relacionado ao estoma ${ }^{3,4}$.

Porém, como o cuidado do ser humano é muito mais complexo e, no qual, concorrem variáveis de diversas naturezas, a proposta preventiva nem sempre é alcançada.

Do ponto de vista da Enfermagem em Estomaterapia, o tratamento das dermatites periestoma baseia-se no diagnóstico e afastamento do(s) fator(es) causal(is) através da modificação do equipamento de coleta utilizado, completa ou parcialmente, e, revisāo do processo de cuidado relacionado ao estoma e pele periestoma ${ }^{2,4,8,10}$.

Em relaçāo à modificação do dispositivo utilizado, é importante lembrar que, tanto do ponto de vista de saúde como econômico, torna-se fundamental "eliminar o supérfluo", is to é, o emprego de agentes para a troca do dispositivo (remoção e colocação), limpeza da pele, os quais podem ser ou transformar-se em agressivos e irritantes. Além disso, embora essenciais para a assistência em Estomaterapia, diversos estudos ${ }^{1,5,7,9}$ têm comprovado a inexistência, até o momento, de barreiras protetoras que sejam totalmente efetivas na prevenção da dermatite (por ação da barreira diretamente sobre a pele ou do efluente, cujo vazamento a barreira possibilite).

Quanto ao segundo aspecto do tratamento, inicialmente é imprescindível que o ensino seja introduzido precocemente, já na fase pré-operatória, garantindo-se ao paciente e/ou familiar a sua continuidade no período pósoperatório tardio, (ambulatorial ou domiciliar), onde possa ser efetivada a avaliação e, assim, a revisão do processo de cuidado adotado.

Certamente alguns outros cuidados deverảo compor este quadro de prevenção e tratamento como:

- a realização do teste de hipersensibilidade a qualquer um dos componentes do dispositivo, em pacientes com história de sensibilização ou que venham a desenvolvê-la;

- o uso de corticoesteróides, antifúngicos ou antibióticos, uma vez prescritos, conhecendo-se suas açōes a repercussōes sobre a pele e o cuidado, e

- o encaminhamento para tratamento cirúrgico nas situaçōes mais drásticas (como tumores em pele periestoma ou estoma e complicaçōes significativas que interferem no cuidar como retraçōes, estenoses, hérnias, prolapsos e outras $)^{4,10}$. 
SANTOS, V. L. C. de G. How I manage the periostoamal skin irritation. Rev. Esc. Enf. USP, v. , n. ,p 67-71, Apr. 1994.

Peristomal skin irritation is one of the most frequent complication in the ostomate's rehabilitation process. It can and must be avoid through a specialized care. The author makes a literature revision and approaches the causative and associated factors to the skin damage, its classification and the preventive and therapeutical principles in Nursing Stomaltherapy.

UNITERMS: Ostomy. Dermatites.

\section{REFERÊNCIAS BIBLIOGRÁFICAS}

01. ANAZAWA, S. et al. Clinical assessment of skin care in ostomy patients. In: BIEN. NIAL CONGRESS OF WCET, $7^{1}$, Suécia, 1988. Proceedings. Suécia, Palex International SA, 1988. p.35.

02. BORGLUND, E. Care of pegigtomal skin. a dermatologist's view. In: BIENNIAL CONGRESS OF WCET, $7^{\text {}}$, Suécia, 1988. Proceedings. Suécia, Palex International SA, 1988. p.30-4.

03. FAZIO, V.W.; TJANDRA, J.J. Prevention and management of ileostomy complications . J.ET Nurs., v.19, n.2, p.48-53, 1992.

04. HAMPTON, B.G. Peristomal and stomal complications. In:

BRYANT, R.A. Ostomies and continent diversions: nursing management.

St.Louis, Mosby, 1992. cap.3, p.105-28.

05. KENJI, T. Bacteriostatical properties of skin barriers. In: BIENNIAL CONGRESS OF WCET, 7 , Suécia, 1988. Proceedings. Suécia, Palex International SA, 1988. p.37-41.

06. NORDSTROM, G. Skin lesions related to the stoma and appliance routines. In: BIENNIAL CONGRESS OF WCET, 7 , Suécia, 1988. Proceedings. Suécia, Palex International SA, 1988. p.36.

07. OHMURA, Y. Clinical analysis of skin carq $b^{2}$ s skin barriers in colostomy patients. In: BIENNIAL CONGReSS OF WCET, 8 , Canada, 1990. Proceedings. Canada, Hollister Incorporated, 1990. p.153.4.

08. ROTHSTEIN, M.S. Continuing medical education: dermatologic considerations of stoma care. J.Am.Acad.Dermatol. v.15, n.3, p. 411-32, 1986.

09. SADAO, A. Karaya Gum - the significant role in periostomal skin care. In: BIENNIAL. CONGRESS ÓF WCET, 8th, Canada, 1990. Proceedings. Canada, Hollister Incorporated, 1990 . p.151-2.

10. WATT, R.C. Pathophysiology of periostomal skin. In: BROADWELL, D.C.; JACKSON, B.S. Principles of ostomy care. St.Louis, Mosby, 1982. cap.20, p.241-53. 